33 Simple Strategies for Faculty 



\title{
33 \\ Simple \\ Strategies \\ for Faculty \\ A Week-by-Week Resource \\ for Teaching First-Year and \\ First-Generation Students
}

\author{
Lisa M. Nunn
}

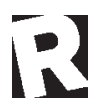

\section{Rutgers University Press}

New Brunswick, Camden, and Newark, New Jersey, and London 
Library of Congress Cataloging-in-Publication Data

Names: Nunn, Lisa M., 1975- author.

Title: 33 simple strategies for faculty : a week-by-week resource for teaching first-year and first-generation students / Lisa M. Nunn.

Other titles: Thirty-three simple strategies for faculty

Description: New Brunswick, New Jersey : Rutgers University Press, 2018. |

Includes bibliographical references.

Identifiers: LCCN 2018004657 | ISBN 9780813599489 (hardback : alk. paper) | ISBN 9780813599472 (paperback : alk. paper)

Subjects: LCSH: College freshmen-United States. | First-generation college students-United States. | College orientation-United States. | Teacherstudent relationships-United States. | College teaching-United States. | BISAC: EDUCATION / Inclusive Education. | EDUCATION / Teaching Methods \& Materials / Social Science. | EDUCATION / Teaching Methods \& Materials / Arts \& Humanities. | EDUCATION / Teaching Methods \& Materials / Science \& Technology.

Classification: LCC LB2343.32 .N86 2018 | DDC 378.1/98-dc23

LC record available at https://lccn.loc.gov/2018004657

A British Cataloging-in-Publication record for this book is available from the British Library.

Copyright (c) 2019 by Lisa M. Nunn All rights reserved

No part of this book may be reproduced or utilized in any form or by any means, electronic or mechanical, or by any information storage and retrieval system, without written permission from the publisher. Please contact Rutgers University Press, 106 Somerset Street, New Brunswick, NJ 08901. The only exception to this prohibition is "fair use" as defined by U.S. copyright law.

$\infty$ The paper used in this publication meets the requirements of the American National Standard for Information Sciences-Permanence of Paper for Printed Library Materials, ANSI Z39.48-1992.

www.rutgersuniversitypress.org

Manufactured in the United States of America 
For my sister, Monica, and my nephews, Nick and Trevor 
